\title{
PENGARUH PROGRAM CORPORATE SOCIAL RESPONSIBILITY (CSR) TERHADAP KESEJAHTERAAN KELUARGA DI SEKITAR TAMBANG
}

\author{
Gilar Cahya Nirmaya ${ }^{1}$, Istiqlaliyah Muflikhati ${ }^{*{ }^{*}}$, Megawati Simanjuntak ${ }^{1}$, \\ ${ }^{1}$ Departemen IImu Keluarga dan Konsumen, Fakultas Ekologi Manusia, Institut Pertanian Bogor, \\ Bogor 16680, Indonesia \\ *) E-mail: muflikhati@yahoo.com
}

\begin{abstract}
Abstrak
Penelitian ini bertujuan untuk menganalisis pengaruh program Corporate Social Responsibility (CSR) terhadap kesejahteraan keluarga di daerah tambang Batulicin, Kalimantan Selatan. Penelitian ini menggunakan kombinasi dari desain cross sectional dan retrospektif. Data dikumpulkan di desa Sarigadung. Responden dalam penelitian ini adalah keluarga miskin, yang dibedakan berdasarkan manfaat yang diterima dari program CSR. Responden berjumlah 70 keluarga yang dipilih secara purposive, separuh diidentifikasi sebagai keluarga penerima program CSR dan lainnya sebagai keluarga nonpenerima program CSR. Hasil penelitian menunjukkan bahwa lebih dari tiga per empat responden menganggap program CSR sangat positif. Pada umumnya, pendapatan keluarga meningkat setelah mengikuti program CSR. Jumlah keluarga miskin di bawah garis kemiskinan menurun dan tingkat kepuasan keluarga meningkat. Jumlah pendapatan keluarga penerima program CSR lebih tinggi daripada keluarga nonpenerima program CSR. Penelitian ini juga menemukan tidak ada perbedaan signifikan antara kesejahteraan subjektif dari keluarga penerima program CSR dan keluarga nonpenerima program CSR. Faktor yang memengaruhi kesejahteraan objektif keluarga penerima program CSR adalah besar keluarga dan manfaat CSR, sedangkan faktor yang memengaruhi kesejahteraan subjektif keluarga penerima program CSR adalah status pekerjaan istri dan manfaat CSR.
\end{abstract}

Kata kunci: kesejahteraan objektif, kesejahteraan subjektif, tanggung jawab sosial perusahaan, wilayah tambang

\section{Influence of Corporate Social Responsibility on Family's Well-being at Surrounding of Mining Area}

\begin{abstract}
This research aimed to analyze the influence of Corporate Social Responsibility (CSR) program onfamily's well-being in Batulicin mining area, South Kalimantan. This study applied a combination of cross-sectional and retrospective design. The data were collected in Sarigadung village. Samples in this study were poor families, whom distinguished by the benefits that received from CSR program. Samples were 70 families that selected purposively; half were identified as CSR program receiver families while other difined as nonreceiver family of CSR program. The results showed that more than three-forth of the samples considered CSR programs were very positive. Generally, the family's income increased after followed CSR program. Number of poor families under the poverty line decreased and the number of satisfied family increased. Total income of receiver families of CSR program was higher than nonreceiver families. This research also found there was no significance difference between subjective wellbeing of receiver and nonreceiver families of CSR program. Factors that affected objective family wellbeing were family size and the benefits of CSR, while the factors that influence subjective family wellbeing were occapation status of wife and the benefits of CSR.
\end{abstract}

Keywords: corporate social responsibility, mining area, objective wellbeing, subjective wellbeing

\section{PENDAHULUAN}

Setiap perusahaan akan melakukan berbagai kegiatan terencana untuk dapat menjaga eksistensinya dan menjadi good bussiness. Salah satu caranya adalah dengan mengikuti peraturan yang telah ditetapkan pemerintah untuk menerapkan tanggung jawab sosial perusahaan (Corporate Social Responsibility atau disingkat dengan CSR).
CSR merupakan komitmen dunia usaha untuk terus menerus bertindak secara etis, beroperasi secara legal dan berkontribusi untuk peningkatan ekonomi, bersamaan dengan peningkatan kualitas hidup dari karyawan dan keluarganya sekaligus juga peningkatan kualitas komunitas lokal dan masyarakat secara luas (The World Bussiness Council for Sustainable Development (WBCSD), diacu dalam Wibisono, 2007). 
Keberadaan program sebagai bentuk tanggung jawab sosial perusahaan sangat banyak di Indonesia dan tersebar di berbagai wilayah. Program-program yang menjadi ruang lingkup tanggung jawab sosial perusahaan mencakup bidang ekonomi, pendidikan, kesehatan, sosial budaya, dan infrastruktur. Menurut Mapisangka (2009) CSR memiliki pengaruh besar terhadap peningkatan kesejahteraan hidup masyarakat di lingkungan Kawasan Batamindo, adapun variabel yang paling besar berpengaruh adalah corporate social program dibandingkan corporate social issue dan corporate social responsibility goal.

Keluarga sebagai unit terkecil dari suatu masyarakat, merupakan bagian dari sasaran program CSR. Masyarakat yang berada di sekitar daerah tambang ikut terkena dampak dari aktifitas pertambangan. Hal tersebut menimbulkan pemikiran dan memotivasi penelitian ini untuk mengetahui dan menganalisis sampai sejauh mana CSR telah memberdayakan dan meningkatkan kesejahteraan serta taraf hidup masyarakat di sekitar wilayah tambang.

Penelitian ini bertujuan untuk menganalisis perbedaan kondisi kesejahteraan keluarga penerima manfaat di sekitar tambang sebelum dan sesudah menerima program CSR, menganalisis perbedaan kondisi kesejahteraan antara keluarga penerima manfaat dengan keluarga bukan penerima program CSR, menelaah persepsi dan manfaat yang dirasakan masyarakat terhadap pelaksanaan CSR, dan menganalisis variabel-variabel yang memengaruhi tingkat kesejahteraan keluarga di sekitar tambang.

\section{METODE}

Desain penelitian ini adalah kombinasi cross sectional dan retrospektif. Penelitian dilakukan di Desa Sarigadung, Kecamatan Simpang Empat, Kabupaten Tanah Bumbu, Provinsi Kalimantan Selatan. Lokasi penelitian dipilih secara purposive dengan pertimbangan bahwa lokasi penelitian merupakan daerah yang telah dimasuki oleh program CSR Tambang Batulicin. Selain itu, wilayah penelitian juga termasuk ke dalam lima desa dengan jumlah keluarga miskin terbanyak. Pengumpulan data dilaksanakan pada bulan Maret hingga bulan April 2011.

Populasi penelitian adalah keluarga miskin yang tinggal di Desa Sarigadung yang berjumlah 217 keluarga. Adapun contoh dalam penelitian adalah 70 keluarga miskin yang dibedakan berdasarkan penerimaan manfaat CSR, yaitu yang telah maupun yang belum mendapat manfaat dari program CSR Tambang Batulicin. Penentuan jumlah contoh dilakukan secara purposive dengan proporsi 35 keluarga penerima manfaat program CSR dan 35 keluarga nonpenerima manfaat program CSR. Penentuan contoh keluarga nonpenerima program CSR dilakukan dengan metode simple random sampling, sementara penentuan responden keluarga penerima program CSR dilakukan dengan metode purposive.

Data primer meliputi karakteristik sosial ekonomi keluarga, kepemilikan aset, pengetahuan responden mengenai program CSR yang ada, kesejahteraan subjektif keluarga, manfaat CSR, dan persepsi responden terhadap program CSR yang ada. Sementara itu, data sekunder meliputi jumlah keluarga miskin di sekitar wilayah Tambang Batulicin, jumlah keluarga yang telah menerima program CSR, jumlah keluarga yang belum menerima program CSR, serta data program CSR Tambang Batulicin yang diperoleh dari arsip perusahaan.

Kesejahteraan keluarga yang diukur dalam penelitian ini adalah kesejahteraan objektif dan kesejahteraan subjektif. Kesejahteraan objektif diukur menggunakan indikator garis kemiskinan BPS. Berdasarkan indikator BPS, keluarga dikatakan miskin jika memiliki pendapatan per kapita per bulan kurang dari garis kemiskinan. Garis kemiskinan yang digunakan untuk menilai kondisi keluarga pada saat sebelum program CSR adalah Garis Kemiskinan wilayah Kabupaten Tanah Bumbu tahun 2005 yaitu sebesar Rp159.347,00 per kapita per bulan. Sementara itu, untuk menilai kondisi kemiskinan keluarga pada saat penerimaan program CSR digunakan Garis Kemiskinan (GK) wilayah Kabupaten Tanah Bumbu tahun 2009 sebesar Rp219.500,00 per kapita per bulan.

Kesejahteraan subjektif diukur dari tingkat kebahagiaan dan kepuasan yang dirasakan oleh keluarga dan anggota keluarga yang menjadi responden penelitian ini. Kesejahteraan subjektif diukur berdasarkan 16 pertanyaan tentang kepuasan responden terhadap pemenuhan kebutuhan pangan, pakaian, kualitas rumah, kualitas pendidikan anak, kesehatan keluarga, dan pemenuhan kebutuhan sosial di dalam masyarakat. Penilaian kesejahteraan subjektif dibagi menjadi tiga, yaitu tidak puas, cukup puas, dan puas. 
Pengetahuan tentang program CSR dinilai dari persentase skor yang diperoleh responden. Berdasarkan persentase skor, pengetahuan tentang program CSR dapat dibedakan menjadi tiga kategori, yaitu: pengetahuan rendah (persentase skor 0,0\%-33,3\%), sedang (persentase skor 33,4\%-66,6\%), dan tinggi (persentase skor 66,7-100\%).

Persepsi dan manfaat program CSR hanya diukur pada keluarga penerima manfaat CSR saja. Persepsi contoh terhadap CSR diukur berdasarkan sembilan pertanyaan terkait pelaksanaan program CSR Tambang Batulicin. Masing-masing pertanyaan diberi skor 0 jika jawaban "tidak setuju" atau "netral", dan skor 1 jika jawaban "setuju". Penelitian ini juga mengukur manfaat yang dirasakan responden setelah mengikuti program CSR dibandingkan dengan kondisi sebelumnya. Data manfaat program CSR diberi skor 1 jika jawaban "turun", skor 2 jika jawaban "tetap", dan skor 3 jika jawaban "naik". Selanjutnya, skor yang diperoleh dari masing-masing pertanyaan dijumlahkan, kemudian dibuat penggolongan interval kelas menjadi tiga kategori yaitu kurang baik, cukup baik, dan baik.

Instrumen yang telah disusun, diuji reliabilitas dan validitasnya. Nilai Cronbach's alpha dari kesejahteraan keluarga subjektif sebesar 0,682, pengetahuan program CSR sebesar 0,750, manfaat program CSR sebesar 0,737, dan persepsi program CSR sebesar 0,701 . Data yang telah dikumpulkan diolah melalui proses editing, coding, scoring, entrying, cleaning, dan selanjutnya dianalisis. Analisis statistik yang digunakan adalah analisis deskriptif dan inferensial, yaitu uji beda Paired t-test, uji beda Independent Samples $t$ test, uji beda Mann-Whitney, uji beda Wilcoxon dan regresi linear berganda.

\section{HASIL}

\section{Karakteristik Keluarga}

Hasil penelitian ini menunjukkan bahwa sebagian besar keluarga baik yang menerima maupun nonpenerima program CSR termasuk dalam keluarga kecil dengan rata-rata jumlah anggota keluarga adalah 4 orang. Rata-rata usia kepala keluarga pada keluarga penerima program CSR lebih tinggi daripada rata-rata usia pada keluarga nonpenerima program CSR. Sementara itu, rata-rata usia istri pada keluarga penerima program CSR lebih rendah dibandingkan dengan keluarga nonpenerima program CSR. Berdasarkan lama sekolah, kepala keluarga dan istri pada keluarga penerima program CSR memiliki rata-rata lama sekolah yang lebih tinggi dibandingkan dengan keluarga nonpenerima program CSR.

Rata-rata pendapatan dan pendapatan per kapita keluarga penerima program CSR lebih besar daripada keluarga nonpenerima program CSR. Rata-rata pengeluaran dan pengeluaran per kapita keluarga penerima program CSR lebih tinggi dari pengeluaran keluarga nonpenerima program CSR. Hasil uji statistik menunjukkan tidak terdapat perbedaan yang signifikan antara besar keluarga, usia kepala keluarga, usia istri, lama pendidikan kepala keluarga, dan lama pendidikan istri antara keluarga penerima program CSR dan keluarga nonpenerima program CSR. Namun, terdapat perbedaan yang signifikan antara pendapatan per bulan, pendapatan per kapita, pengeluaran per bulan, dan pengeluaran per kapita antara keluarga penerima program CSR dan keluarga nonpenerima program CSR (Tabel 1).

Tabel 1 Nilai rata-rata, standar deviasi, dan koefisien uji beda karakteristik keluarga penerima dan nonpenerima program CSR

\begin{tabular}{|c|c|c|c|}
\hline \multirow[b]{2}{*}{$\begin{array}{c}\text { Karakteristik } \\
\text { keluarga }\end{array}$} & \multicolumn{2}{|c|}{$\begin{array}{c}\text { Rata-rata } \pm \text { Standar } \\
\text { deviasi }\end{array}$} & \multirow[b]{2}{*}{$p$-value } \\
\hline & $\begin{array}{l}\text { Penerima } \\
\text { program } \\
\text { CSR }\end{array}$ & $\begin{array}{l}\text { Non- } \\
\text { penerima } \\
\text { program } \\
\text { CSR } \\
\end{array}$ & \\
\hline $\begin{array}{l}\text { Besar } \\
\text { keluarga } \\
\text { (orang) }\end{array}$ & $4,2 \pm 1,3$ & $3,9 \pm 1,4$ & 0,303 \\
\hline $\begin{array}{l}\text { Usia kepala } \\
\text { keluarga } \\
\text { (tahun) }\end{array}$ & $45,6 \pm 13,2$ & $43,2 \pm 19,9$ & 0,549 \\
\hline $\begin{array}{l}\text { Usia istri } \\
\text { (tahun) }\end{array}$ & $38,3 \pm 12,6$ & $39,6 \pm 14,9$ & 0,692 \\
\hline $\begin{array}{l}\text { Lama } \\
\text { pendidikan } \\
\text { kepala } \\
\text { keluarga } \\
\text { (tahun) }\end{array}$ & $5,5 \pm 3,5$ & $3,8 \pm 3,1$ & 0,160 \\
\hline $\begin{array}{l}\text { Lama } \\
\text { pendidikan } \\
\text { istri (tahun) }\end{array}$ & $4,5 \pm 3,3$ & $3,4 \pm 2,7$ & 0,160 \\
\hline $\begin{array}{l}\text { Pendapatan } \\
\text { keluarga } \\
\text { (Rp/bulan) }\end{array}$ & $\begin{array}{r}1.731 .100 \pm \\
1.205 .570\end{array}$ & $\begin{array}{r}950.250 \pm \\
739.920\end{array}$ & $0,002^{* * *}$ \\
\hline $\begin{array}{l}\text { Pendapatan } \\
\text { per kapita } \\
\text { (Rp/bulan) }\end{array}$ & $\begin{array}{r}441.895,7 \pm \\
301.720,9\end{array}$ & $\begin{array}{r}285.660 \pm \\
239.216,4\end{array}$ & $0,019^{* *}$ \\
\hline $\begin{array}{l}\text { Pengeluaran } \\
\text { keluarga } \\
\text { (Rp/bulan) }\end{array}$ & $\begin{array}{r}1.797 .740 \pm \\
923.830\end{array}$ & $\begin{array}{r}1.329 .680 \pm \\
861.500\end{array}$ & $0,032^{* *}$ \\
\hline $\begin{array}{l}\text { Pengeluaran } \\
\text { per kapita } \\
\text { (Rp/bulan) }\end{array}$ & $\begin{array}{r}449.835 \pm \\
208.668,9\end{array}$ & $\begin{array}{r}350.565 \pm \\
180.785,6\end{array}$ & $0,037^{* *}$ \\
\hline
\end{tabular}

Keterangan:

**Signifikan pada $p<0,05,{ }^{* *}$ Signifikan pada $p<0,01$ 
Tabel 2 Nilai rata-rata, standar deviasi, dan koefisien uji beda pendapatan pada keluarga penerima program CSR sebelum dan sesudah menerima program CSR

\begin{tabular}{|c|c|c|c|}
\hline \multirow{2}{*}{$\begin{array}{c}\text { Karakteristik } \\
\text { keluarga }\end{array}$} & \multicolumn{2}{|c|}{ Penerima program CSR } & \multirow[b]{2}{*}{$p$-value } \\
\hline & $\begin{array}{l}\text { Sebelum } \\
\text { menerima }\end{array}$ & $\begin{array}{c}\text { Setelah } \\
\text { menerima }\end{array}$ & \\
\hline $\begin{array}{l}\text { Pendapatan } \\
\text { (Rp/bulan) }\end{array}$ & $\begin{array}{c}1.134 .750 \pm \\
1.001 .850\end{array}$ & $\begin{array}{c}1.731 .100 \pm \\
1.205 .570\end{array}$ & $0,000^{\star * \star}$ \\
\hline $\begin{array}{l}\text { Pendapatan } \\
\text { per kapita } \\
\text { (Rp/bulan) }\end{array}$ & $\begin{array}{c}300.570 \pm \\
234.914\end{array}$ & $\begin{array}{c}441.895 \pm \\
301.720 \\
\end{array}$ & $0,000^{\star * *}$ \\
\hline
\end{tabular}

Hasil penelitian yang disajikan pada Tabel 2 juga menunjukkan bahwa keluarga pada saat sebelum mengikuti program CSR memiliki pendapatan rata-rata sebesar Rp1.134.750,00 per bulan dengan rata-rata pendapatan per kapita sebesar Rp300.570,00 per bulan. Setelah mengikuti program CSR, keluarga memiliki pendapatan rata-rata sebesar Rp1.731.100,00 per bulan dengan rata-rata pendapatan per kapita sebesar Rp441.895,00 per bulan. Rata-rata pendapatan keluarga pada saat menerima program CSR lebih besar dibandingkan dengan sebelum menerima program CSR. Hal ini menunjukkan bahwa terjadinya peningkatan pendapatan keluarga setelah mengikuti program CSR.

Rata-rata pendapatan keluarga nonpenerima program CSR adalah Rp950.250,00 per bulan dan pendapatan keluarga per kapita sebesar Rp285.660,00 per bulan. Hasil uji beda juga menunjukkan terdapat perbedaan yang signifikan pada pendapatan keluarga per bulan dan pendapatan keluarga per kapita antara keluarga penerima program CSR dan keluarga nonpenerima program CSR.

\section{Kesejahteraan Keluarga}

Kesejahteraan objektif. Hampir separuh keluarga penerima program CSR berada dalam kategori miskin sebelum adanya program CSR. Setelah menerima program CSR, terdapat penurunan persentase keluarga miskin pada keluarga penerima program CSR sebesar 8,6 persen. Hasil tabulasi silang pendapatan per kapita keluarga penerima program CSR dan nonpenerima program CSR dengan menggunakan standar garis kemiskinan menunjukkan bahwa kurang dari sepertiga keluarga penerima program CSR termasuk dalam kategori miskin (Tabel 3). Adapun lebih dari separuh keluarga nonpenerima program CSR termasuk dalam kategori miskin.
Tabel 3 Sebaran tingkat kesejahteraan keluarga berdasarkan indikator garis kemiskinan BPS

\begin{tabular}{|c|c|c|c|}
\hline \multirow{2}{*}{$\begin{array}{c}\text { Tingkat } \\
\text { kesejahteraan }\end{array}$} & \multicolumn{2}{|c|}{ Penerima program CSR } & \multirow{2}{*}{$\begin{array}{c}\text { Non } \\
\text { penerima } \\
\text { program }\end{array}$} \\
\hline & $\begin{array}{c}\text { Sebelum } \\
\text { menerima }\end{array}$ & $\begin{array}{c}\text { Saat } \\
\text { menerima }\end{array}$ & \\
\hline Miskin (< GK) & 40,0 & 31,4 & 51,4 \\
\hline $\begin{array}{l}\text { Hampir } \\
\text { miskin }(1,00 \text { - } \\
1,25 \mathrm{GK})\end{array}$ & 0,0 & 5,7 & 14,3 \\
\hline $\begin{array}{l}\text { Hampir tidak } \\
\text { miskin }(1,25- \\
1,5 \mathrm{GK})\end{array}$ & 14,3 & 11,4 & 0,0 \\
\hline $\begin{array}{l}\text { Tidak miskin } \\
(>1,50 \mathrm{GK})\end{array}$ & 45,7 & 51,4 & 34,3 \\
\hline Total & 100,0 & 100,0 & 100,0 \\
\hline $\begin{array}{l}\text { Minimum- } \\
\text { maksimum } \\
\text { (Rp/bulan) }\end{array}$ & $\begin{array}{c}22.500- \\
1.000 .000\end{array}$ & $\begin{array}{c}41.700- \\
1.100 .000\end{array}$ & $\begin{array}{l}15.900- \\
860.000\end{array}$ \\
\hline $\begin{array}{l}\text { Rata-rata } \pm \\
\text { Standar } \\
\text { deviasi } \\
\text { (Rp/bulan) }\end{array}$ & $\begin{array}{c}300.570 \pm \\
234.914\end{array}$ & $\begin{array}{c}441.895 \pm \\
301.720\end{array}$ & $\begin{array}{c}285.660 \pm \\
239.216\end{array}$ \\
\hline$p$-value & & $0^{* * *}$ & $0,019^{\star *}$ \\
\hline
\end{tabular}

Keterangan:

${ }^{*}$ Signifikan pada $p<0,05,{ }^{* \star *}$ Signifikan pada $p<0,01$

Hasil uji beda $t$ yang disajikan pada Tabel 3 menunjukkan bahwa terdapat perbedaan yang signifikan antara pendapatan per kapita keluarga penerima program CSR antara sebelum dan sesudah menerima program CSR. Selain itu, juga ditemukan adanya perbedaan yang signifikan antara pendapatan keluarga per kapita enerima program CSR dengan keluarga nonpenerima program CSR. Pendapatan keluarga penerima program CSR lebih tinggi dibandingkan nonpenerima program CSR.

Kesejahteraan subjektif. Hasil penelitian menunjukkan bahwa sebelum adanya program CSR, tidak ada keluarga yang merasa puas dengan kondisi keluarganya. Namun, setelah mengikuti program CSR terdapat sebagian kecil responden $(20 \%)$ yang merasa puas terhadap kondisi keluarganya. Hasil uji beda Wilcoxon menunjukkan perbedaan yang sangat signifikan $(p<0,01)$ antara kesejahteraan subjektif keluarga sebelum dan sesudah mengikuti program CSR. Hasil penelitian yang disajikan pada Tabel 4 menunjukkan bahwa lebih dari separuh keluarga merasa sudah cukup puas dengan keadaan keluarganya selama ini (60,0\% pada keluarga penerima program CSR dan $62,9 \%$ pada keluarga nonpenerima program CSR). Hasil uji beda Mann-Whitney menunjukkan tidak terdapat perbedaan yang signifikan $(p>0,1)$ antara kesejahteraan subjektif keluarga penerima program CSR saat ini dengan keluarga nonpenerima program CSR. 
Tabel 4 Sebaran kesejahteraan keluarga responden berdasarkan kategori kesejahteraan subjektif

\begin{tabular}{|c|c|c|c|}
\hline \multirow[b]{2}{*}{$\begin{array}{c}\text { Tingkat } \\
\text { kesejahteraan }\end{array}$} & \multicolumn{2}{|c|}{$\begin{array}{c}\text { Penerima program } \\
\text { CSR }\end{array}$} & \multirow{2}{*}{$\begin{array}{c}\text { Non } \\
\text { penerima } \\
\text { program } \\
\text { CSR } \\
(\mathrm{n}=35)\end{array}$} \\
\hline & $\begin{array}{c}\text { Sebelum } \\
\text { menerima } \\
(n=35)\end{array}$ & $\begin{array}{c}\text { Saat } \\
\text { menerima } \\
(\mathrm{n}=35)\end{array}$ & \\
\hline Tidak puas & 34,3 & 20,0 & 25,7 \\
\hline Cukup puas & 65,7 & 60,0 & 62,9 \\
\hline Puas & 0,0 & 20,0 & 11,4 \\
\hline Total & 100,0 & 100,0 & 100,0 \\
\hline $\begin{array}{l}\text { Minimum- } \\
\text { maksimum } \\
\text { (\% kepuasan) } \\
\text { Rata-rata } \pm\end{array}$ & $\begin{array}{r}12,5- \\
65,6\end{array}$ & $\begin{array}{r}15,6- \\
81,3\end{array}$ & $\begin{array}{r}18,8- \\
96,9\end{array}$ \\
\hline $\begin{array}{l}\text { Standar } \\
\text { deviasi (\% } \\
\text { kepuasan) }\end{array}$ & $\begin{array}{r}39,03 \pm \\
14,79\end{array}$ & $\begin{array}{r}51,08 \pm \\
17,5\end{array}$ & $\begin{array}{r}46,70 \pm \\
17,96\end{array}$ \\
\hline$p$-value & & $0,000 * * *$ & 0,192 \\
\hline
\end{tabular}

\section{Pengetahuan tentang Program CSR}

Hasil penelitian menunjukkan bahwa keluarga penerima program CSR memiliki tingkat pengetahuan tentang program CSR Tambang Batulicin lebih tinggi dibandingkan dengan keluarga nonpenerima program CSR. Hasil penelitian juga menunjukkan bahwa terdapat proporsi yang sama pada keluarga penerima program CSR antara yang memiliki pengetahuan rendah dan tinggi mengenai pelaksanaan program CSR yaitu sebesar 40 persen. Lebih dari tiga per empat keluarga nonpenerima program CSR memiliki pengetahuan yang rendah mengenai pelaksanaan program CSR. Hasil uji beda Mann-Whitney menunjukkan terdapat perbedaan yang signifikan $(p<0,01)$ antara tingkat pengetahuan keluarga penerima dan nonpenerima program CSR (Tabel 5).

Tabel 5 Sebaran keluarga berdasarkan pengetahuan tentang program CSR

\begin{tabular}{|c|c|c|}
\hline $\begin{array}{c}\text { Kategori } \\
\text { Pengetahuan }\end{array}$ & $\begin{array}{c}\text { Penerima } \\
\text { program } \\
\text { CSR }(n=35)\end{array}$ & $\begin{array}{c}\text { Nonpenerima } \\
\text { program } \\
\text { CSR }(n=35)\end{array}$ \\
\hline Rendah & 40,0 & 77,1 \\
\hline Sedang & 20,0 & 20,0 \\
\hline Tinggi & 40,0 & 2,9 \\
\hline Total & 100,0 & 100,0 \\
\hline $\begin{array}{l}\text { Minimum- } \\
\text { maksimum (\% } \\
\text { pengetahuan) }\end{array}$ & $\begin{array}{r}13,3- \\
93,3\end{array}$ & $0,0-73,3$ \\
\hline $\begin{array}{l}\text { Rata-rata } \pm \\
\text { standar deviasi } \\
\text { (\% pengetahuan) }\end{array}$ & $50,7 \pm 26,2$ & $18,5 \pm 20,6$ \\
\hline$p$-value & \multicolumn{2}{|c|}{$0,000^{* * *}$} \\
\hline
\end{tabular}

Tabel 6 Sebaran keluarga penerima program CSR berdasarkan persepsi dan manfaat program CSR

\begin{tabular}{lr}
\hline \multicolumn{1}{c}{ Kategori } & $\begin{array}{r}\text { Persentase } \\
(\%)\end{array}$ \\
\hline Persepsi tehadap program CSR & 14,3 \\
Kurang baik & 8,6 \\
Cukup baik & 77,1 \\
Baik & 100,0 \\
\hline Total & $0-100$ \\
Minimum-maksimum (\% persepsi) & \\
Rata-rata \pm Standar deviasi (\% & 0,0 \\
persepsi) & $70,8 \pm 32,1$ \\
\hline Manfaat yang dirasakan & 57,1 \\
Rendah & 42,9 \\
Sedang & 100,0 \\
Tinggi & $43,3-$ \\
\hline Total & 83,3 \\
Minimum-maksimum (\% manfaat) & \\
Rata-rata \pm Standar deviasi (\% & $65,4 \pm 10,3$ \\
\hline manfaat)
\end{tabular}

\section{Persepsi dan Manfaat Program CSR}

Persepsi tentang program CSR diukur dari pengetahuan dan pandangan seseorang mengenai keberadaan Tambang Batulicin, tujuan, kualitas pelaksanaan, dan dampak dari pelaksanaan program CSR perusahaan tersebut. Hasil penelitian menunjukkan bahwa lebih dari tiga per empat keluarga penerima program CSR berada pada kategori yang mempersepsikan bahwa pelaksanaan program CSR Tambang Batulicin dinilai baik. Sebaran keluarga penerima program CSR berdasarkan persepsi dan manfaat program CSR disajikan pada Tabel 6.

Hasil penelitian juga menunjukkan bahwa lebih dari separuh keluarga penerima program CSR $(57,1 \%)$ menilai bahwa program CSR Tambang Batulicin termasuk dalam kategori sedang atau cukup bermanfaat. Hal ini disebabkan sebagian besar manfaat yang dirasakan keluarga adalah termasuk tetap atau tidak mengalami perubahan saat keluarga mengikuti program CSR hingga saat ini.

\section{Variabel-variabel yang Memengaruhi Tingkat Kesejahteraan Keluarga Sekitar Tambang}

Model regresi yang dibangun untuk menganalisis kesejahteraan objektif memiliki koefisien determinasi sebesar 0,186 (Tabel 7). Model ini menemukan bahwa kesejahteraan keluarga objektif dipengaruhi oleh status keluarga apakah termasuk keluarga penerima program CSR (positif) dan besar keluarga (negatif). 
Tabel 7 Koefisien regresi variabel yang memengaruhi tingkat kesejahteraan objektif keluarga

\begin{tabular}{|c|c|c|c|}
\hline Variabel & $B$ & $\beta$ & Sig \\
\hline Konstanta & $558.912,7$ & - & 0,008 \\
\hline $\begin{array}{l}\text { Status } \\
\text { penerima } \\
\text { program } \\
\text { CSR } \\
(0=\text { tidak, } \\
1=\text { ya) }\end{array}$ & $182.787,9$ & 0,327 & $0,020^{* *}$ \\
\hline $\begin{array}{l}\text { Besar } \\
\text { keluarga } \\
\text { (orang) }\end{array}$ & $-85,936,6$ & $-0,422$ & $\begin{array}{r}0,000^{* *} \\
\text { * }\end{array}$ \\
\hline $\begin{array}{l}\text { Umur kepala } \\
\text { keluarga } \\
\text { (tahun) }\end{array}$ & $1,461,982$ & 0,087 & 0,439 \\
\hline $\begin{array}{l}\text { Lama } \\
\text { pendidikan } \\
\text { kepala } \\
\text { keluarga } \\
\text { (tahun) }\end{array}$ & $3,779,2$ & 0,046 & 0,692 \\
\hline $\begin{array}{l}\text { Status } \\
\text { pekerjaan } \\
\text { istri }(0=\text { tidak } \\
\text { bekerja, } \\
1=\text { bekerja) }\end{array}$ & $34,815,4$ & 0,062 & 0,583 \\
\hline $\begin{array}{l}\text { Pengetahua } \\
\text { n tentang } \\
\text { program } \\
\text { CSR (skor) }\end{array}$ & $-1,863,7$ & $-0,028$ & 0,833 \\
\hline $\mathrm{F}$ & & & 3,630 \\
\hline Sig & & & $0,004^{\star *}$ \\
\hline $\mathrm{R}$ & & & 0,507 \\
\hline $\begin{array}{l}\text { Adjusted } R \\
\text { Square }\end{array}$ & & & 0,186 \\
\hline $\begin{array}{l}\text { Keterangan: } \\
\text { * Signfikan pac } \\
\text { B=Beta tidak ter }\end{array}$ & $\begin{array}{l}<0,05 \\
\text { dardisasi. }\end{array}$ & an & $\begin{array}{l}p<0,01 \\
\text { ssi }\end{array}$ \\
\hline
\end{tabular}

Keikutsertaan dalam program CSR akan meningkatkan kesejahteraan objektif yang diukur dari pendapatan per kapita keluarga. Keluarga yang merupakan peserta program CSR akan mengalami peningkatan pendapatan keluarga sebesar Rp182.787,90 per kapita per bulan. Sementara, penambahan satu anggota keluarga pada keluarga penerima program CSR akan menurunkan kesejahteraan objektif yang mana keluarga tersebut akan mengalami penurunan pendapatan keluarga sebesar Rp85.936,60 per kapita per bulan.

Sementara itu, model regresi yang dibangun untuk menganalisis kesejahteraan subjektif keluarga menunjukkan bahwa model yang dibangun memiliki koefisien determinasi sebesar 0,024 (Tabel 8). Nilai ini menunjukkan bahwa model yang dibangun hanya dapat menjelaskan sebesar 2,4 persen pengaruh variabel-variabel yang ada dalam model terhadap kesejahteraan subjektif keluarga.
Tabel 8 Koefisien regresi yang memengaruhi tingkat kesejahteraan subjektif keluarga

\begin{tabular}{|c|c|c|c|}
\hline Variabel & $B$ & $\beta$ & Sig \\
\hline Konstanta & 26,4 & - & 0,000 \\
\hline $\begin{array}{l}\text { Penerima } \\
\text { manfaat CSR } \\
(0=\text { tidak, } 1=y a)\end{array}$ & 0,18 & 0,016 & 0,919 \\
\hline $\begin{array}{l}\text { Besar } \\
\text { keluarga } \\
\text { (orang) }\end{array}$ & 0,966 & 0,235 & $0,087^{*}$ \\
\hline $\begin{array}{l}\text { Umur kepala } \\
\text { keluarga } \\
\text { (tahun) }\end{array}$ & $-0,018$ & $-0,052$ & 0,672 \\
\hline $\begin{array}{l}\text { Lama } \\
\text { pendidikan } \\
\text { kepala } \\
\text { keluarga } \\
\text { (tahun) }\end{array}$ & 0,284 & 0,170 & 0,182 \\
\hline $\begin{array}{l}\text { Status } \\
\text { pekerjaan istri } \\
(0=\text { tidak } \\
\text { bekerja, } \\
1=\text { bekerja })\end{array}$ & 0,721 & 0,063 & 0,608 \\
\hline $\begin{array}{l}\text { Pengetahuan } \\
\text { tentang } \\
\text { program CSR } \\
\text { (skor) }\end{array}$ & $-0,060$ & $-0,045$ & 0,759 \\
\hline $\begin{array}{l}\text { Pendapatan } \\
\text { per kapita } \\
\text { (Rp/bulan) }\end{array}$ & $4,492 \times 10_{6}^{-}$ & 0,223 & 0,111 \\
\hline $\mathrm{F}$ & & & 1,243 \\
\hline Sig & & & 0,293 \\
\hline $\mathrm{R}$ & & & 0,351 \\
\hline $\begin{array}{l}\text { Adjusted R } \\
\text { Square }\end{array}$ & & & 0,024 \\
\hline
\end{tabular}

Hasil analisis yang disajikan pada Tabel 8 menemukan bahwa dari tujuh variabel yang diduga berpengaruh terhadap kesejahteraan subjektif, hanya terdapat satu variabel yang berpengaruh secara signifikan, yaitu besar keluarga dengan nilai koefisien $\beta$ sebesar 0,235 . Besar keluarga memiliki pengaruh yang positif terhadap kesejahteraan subjektif keluarga. Hasil ini memperlihatkan bahwa penambahan satu anggota keluarga pada keluarga akan meningkatkan kesejahteraan subjektif keluarga, yang mana keluarga tersebut akan mengalami peningkatan skor kesejahteraan subjektif keluarga sebesar 0,966.

\section{Variabel-variabel yang Memengaruhi Tingkat Kesejahteraan Keluarga Penerima Program CSR}

Hasil analisis regresi untuk menganalisis variabel-variabel yang memengaruhi kesejahteraan keluarga disajikan pada Tabel 9 
Tabel 10. Model regresi yang dibangun untuk menganalisis tingkat kesejahteraan objektif keluarga penerima program CSR memiliki koefisien determinasi sebesar 0,143 . Hal ini berarti bahwa model ini hanya dapat menjelaskan 14,3 persen pengaruh variabel bebas yang terdapat dalam model terhadap kesejahteraan objektif keluarga penerima program CSR, sedangkan sisanya dijelaskan oleh variabel lain yang tidak diteliti.

Hasil uji regresi menemukan bahwa hanya terdapat dua dari tujuh variabel yang memengaruhi kesejahteraan objektif keluarga penerima penerima CSR secara signifikan yaitu besar keluarga dan manfaat yang dirasakan keluarga terhadap program CSR (Tabel 9). Besar keluarga memiliki pengaruh negatif terhadap kesejahteraan objektif. Hasil ini menunjukkan bahwa pertambahan jumlah anggota keluarga dapat mengurangi kesejahteraan objektif keluarga. Sementara itu, manfaat yang dirasakan memiliki pengaruh positif terhadap kesejahteraan objektif keluarga penerima program CSR. Penambahan manfaat yang dirasakan keluarga pada program CSR meningkatkan kesejahteraan objektif keluarga.

Tabel 9 Koefisien regresi variabel yang memengaruhi tingkat kesejahteraan objektif keluarga penerima program CSR

\begin{tabular}{|c|c|c|c|}
\hline Variabel & $B$ & $\beta$ & Sig \\
\hline Konstanta & $-264,703,4$ & - & 0,686 \\
\hline $\begin{array}{l}\text { Besar keluarga } \\
\text { (orang) }\end{array}$ & $-103,246,9$ & $-0,445$ & 0,025* \\
\hline $\begin{array}{l}\text { Umur kepala } \\
\text { keluarga (tahun) }\end{array}$ & 1,204 & 0,053 & 0,775 \\
\hline $\begin{array}{l}\text { Lama pendidikan } \\
\text { kepala keluarga } \\
\text { (tahun) }\end{array}$ & $13,811,4$ & 0,162 & 0,330 \\
\hline $\begin{array}{l}\text { Status pekerjaan } \\
\text { istri }(0=\text { tidak } \\
\text { bekerja, } \\
1=\text { bekerja })\end{array}$ & $137,534,1$ & 0,230 & 0,209 \\
\hline $\begin{array}{l}\text { Pengetahuan } \\
\text { tentang program } \\
\text { CSR (skor) }\end{array}$ & $-14,442,2$ & $-0,188$ & 0,347 \\
\hline $\begin{array}{l}\text { Persepsi tentang } \\
\text { program CSR } \\
\text { (skor) }\end{array}$ & $18.331,9$ & 0,176 & 0,406 \\
\hline $\begin{array}{l}\text { Manfaat yang } \\
\text { dirasakan (skor) }\end{array}$ & $33,401,6$ & 0,343 & $0,069^{*}$ \\
\hline $\mathrm{F}$ & & & 1,813 \\
\hline Sig. & & & 0,126 \\
\hline $\mathrm{R}$ & & & 0,565 \\
\hline $\begin{array}{l}\text { Adjusted } R \\
\text { Square }\end{array}$ & & & 0,143 \\
\hline $\begin{array}{l}\text { Keterangan: } \\
B=\text { Beta tidak terstand } \\
\text { Signifikan pada } p<0,\end{array}$ & ${ }^{*}$ Signifik & $0<0$ & \\
\hline
\end{tabular}

Tabel 10 Koefisien regresi variabel yang memengaruhi tingkat kesejahtera-an subjektif keluarga penerima program CSR

\begin{tabular}{|c|c|c|c|}
\hline Variabel & $B$ & $\beta$ & Sig \\
\hline $\begin{array}{l}\text { Besar keluarga } \\
\text { (orang) }\end{array}$ & 0,859 & 0,200 & 0,345 \\
\hline $\begin{array}{l}\text { Umur kepala } \\
\text { keluarga (tahun) }\end{array}$ & 0,051 & 0,120 & 0,522 \\
\hline $\begin{array}{l}\text { Lama pendidikan } \\
\text { kepala keluarga } \\
\text { (tahun) }\end{array}$ & 0,390 & 0,246 & 0,152 \\
\hline $\begin{array}{l}\text { Pekerjaan istri } \\
\text { (0=tidak bekerja, } \\
1=\text { bekerja) }\end{array}$ & 4,013 & 0,362 & $0,062^{*}$ \\
\hline $\begin{array}{l}\text { Pengetahuan } \\
\text { CSR (skor) }\end{array}$ & $-0,165$ & $-0,116$ & 0,570 \\
\hline $\begin{array}{l}\text { Manfaat csr } \\
\text { (skor) }\end{array}$ & 0,613 & 0,339 & $0,093^{*}$ \\
\hline $\begin{array}{l}\text { Persepsi csr } \\
\text { (skor) }\end{array}$ & $-0,026$ & $-0,013$ & 0,950 \\
\hline $\begin{array}{l}\text { Penghasilan per } \\
\text { kapita (Rp/bulan) }\end{array}$ & $2.273 \times 10^{-6}$ & 0,122 & 0,533 \\
\hline $\mathrm{F}$ & & & 1,642 \\
\hline Sig. & & & 0,161 \\
\hline $\mathrm{R}$ & & & 0,579 \\
\hline $\begin{array}{l}\text { Adjusted } R \\
\text { Square }\end{array}$ & & & 0,131 \\
\hline
\end{tabular}

Keterangan:

*Signifikan pada $\mathrm{p}<0,1, \mathrm{~B}=$ Beta tidak terstandardisasi, $\beta=$ Beta terstandardisasi

Tabel 10 menyajikan koefisien regresi dari model yang digunakan untuk menganalisis variabel yang memengaruhi tingkat kesejahteraan subjektif keluarga penerima program CSR. Model regresi yang dibangun untuk memiliki koefisien determinasi sebesar 0,131. Artinya model hanya dapat menjelaskan sebesar 13,1 persen pengaruh variabel bebas dalam model terhadap kesejahteraan keluarga subjektif. Hasil analisis menemukan bahwa dari delapan variabel yang berpengaruh terhadap kesejahteraan subjektif, terdapat dua variabel yang berpengaruh signifikan dan positif yaitu status pekerjaan istri dan manfaat yang dirasakan dengan adanya CSR (Tabel 10). Keluarga penerima program CSR dengan istri yang bekerja akan meningkatkan skor kesejahteraan subjektif keluarga sebesar 4,013. Demikian juga halnya dengan peningkatan keluarga dalam merasakan manfaat CSR maka akan meningkatkan kesejahteraan subjektif.

\section{PEMBAHASAN}

Hasil penelitian menunjukkan adanya perbedaan yang signifikan pada beberapa karakteristik antara keluarga penerima program CSR dan nonpenerima program CSR. Berdasarkan pendapatan keluarga, terdapat 
perbedaan yang signifikan pada pendapatan keluarga sebelum dan sesudah menerima program CSR. Selain itu, juga ditemukan adanya perbedaan yang signifikan pada pendapatan keluarga antara keluarga penerima dan nonpenerima program CSR. Keluarga penerima program CSR memiliki rata-rata pendapatan keluarga Rp1.731.100,00 per bulan saat menjadi peserta program CSR. Pendapatan ini lebih besar daripada pendapatan sebelum menerima program CSR yang hanya memiliki rata-rata pendapatan sebesar Rp1.134.750,00 per bulan. Pendapatan keluarga saat menjadi penerima program CSR juga lebih besar dibandingkan dengan keluarga nonpenerima program CSR yang hanya memiliki rata-rata pendapatan Rp950.250,00 per bulan. Demikian pula dengan pendapatan per kapita yang mana rata-rata pendapatan per kapita keluarga pada saat menerima program CSR sebesar Rp441.895,00 per bulan lebih besar dibandingkan dengan sebelum menerima CSR yang hanya memiliki rata-rata pendapatan per kapita sebesar Rp300.570,00 per bulan dan keluarga nonpenerima program CSR sebesar Rp285.660,00 per bulan.

Pelaksanaan program CSR secara bertahap dan belum menyeluruh di wilayah Desa Sarigadung dapat menyebabkan perbedaan pengetahuan dan persepsi bagi masyarakat. Hasil uji beda menunjukkan terdapat perbedaan yang signifikan antara tingkat pengetahuan keluarga penerima program CSR dengan keluarga nonpenerima program CSR mengenai program CSR Tambang Batulicin. Hal yang menarik pada keluarga penerima program CSR adalah terdapat proporsi yang sama besar antara keluarga yang memiliki tingkat pengetahuan tinggi dan rendah.

Lebih dari tiga per empat keluarga nonpenerima program CSR dan hampir separuh keluarga CSR memiliki pengetahuan yang rendah. Hal yang lebih mengejutkan adalah masih banyak keluarga yang tidak mengetahui apa itu perusahaan pengelola program CSR di Tambang Batulicin, bahkan ada yang menyebutkan bahwa perusahaan tersebut merupakan perusahaan semen. Selain itu, masih banyak juga keluarga yang tidak mengetahui bahwa adanya program CSR di wilayah Tambang Batulicin. Ketidaktahuan keluarga tentang program CSR menyebabkan rendahnya skor pengetahuan keluarga tentang CSR. Hal ini diduga karena kurang optimalnya sosialisasi program ke masyarakat.
Keluarga yang menerima program CSR merasakan manfaat dari keberadaan program tersebut. Manfaat utama yang dirasakan adalah adanya peningkatan pendapatan keluarga, pengeluaran nonpangan keluarga, jumlah kepemilikan aset, serta modal usaha. Sejalan dengan penelitian Simanjuntak, Puspitawati, dan Djamaludin (2010), peningkatan pendapatan total keluarga juga dirasakan sebagai manfaat utama dari adanya Program Keluarga Harapan (PKH), program sejenis guna memberdayakan keluarga miskin.

Dampak dari pelaksanaan program CSR Tambang Batulicin pada tahun 2006 hingga tahun 2011 dapat berpengaruh terhadap kesejahteraan keluarga, baik secara objektif maupun subjektif. Hal ini dapat dilihat dari segi kesejahteraan objektif, semenjak berjalannya program CSR, terdapat penurunan keluarga miskin sebesar 8,6 persen. Dengan demikian dapat dikatakan bahwa program CSR telah mampu menurunkan proporsi keluarga miskin setelah berjalan lima tahun walaupun tingkat penurunannya belum mencapai target (kurang dari $100 \%$ ). Penurunan proporsi keluarga miskin ini disebabkan telah terbukanya peluang usaha bagi keluarga penerima program, yang mana mereka dapat meminjam uang di Lembaga Keuangan Desa (LKD) sebagai modal usaha. Hanya saja, pada pelaksanaannya, masih banyak juga keluarga yang gagal dalam melakukan usaha dan mengembalikan pinjaman. Program pinjaman dana mitra ini bagaikan dua sisi mata uang. Apabila suatu keluarga dapat melakukan pinjaman dan menjalankan usaha dengan terencana maka pinjaman ini dapat meningkatkan kesejahteraan keluarga tersebut, akan tetapi banyak juga keluarga yang gagal dalam menjalankan usahanya dan kehabisan modal sehingga pinjaman ini dapat semakin membelit keluarga tersebut dengan kemiskinan. Walaupun demikian, hasil tabulasi silang antara pendapatan per kapita keluarga penerima dan nonpenerima program CSR yang menggunakan standar garis kemiskinan menunjukkan bahwa hanya kurang dari sepertiga keluarga penerima program CSR $(31,4 \%)$ yang termasuk dalam kategori miskin.

Adapun lebih dari separuh keluarga nonpenerima program CSR termasuk dalam kategori miskin $(51,4 \%)$. Hal ini juga menunjukkan bahwa program CSR bermanfaat dalam hal peningkatan kesejahteraan keluarga terbukti dengan kondisi kesejahteraan keluarga penerima program CSR yang lebih baik. Hasil ini mendukung penelitian sebelumnya terkait dampak program kemitraan bina lingkungan 
yang berpengaruh signifikan terhadap pendapatan masyarakat di lingkungan PTPN III (Karlos, 2009).

Berdasarkan kesejahteraan subjektif, terdapat peningkatan kepuasan keluarga sebelum dan sesudah menerima program CSR. Pada saat sebelum program CSR, tidak ada keluarga yang merasa puas dengan kondisi keluarganya, namun setelah adanya program CSR terdapat 20 persen keluarga yang sudah merasa puas. Hal ini sejalan dengan peningkatan pendapatan yang terjadi pada keluarga sebelum dan sesudah CSR. Semakin baik kondisi ekonomi keluarga maka keluarga tersebut cenderung semakin puas.

Hal yang menarik dalam penelitian ini adalah tidak terdapat perbedaan yang signifikan antara kesejahteraan subjektif keluarga penerima program CSR dengan keluarga nonpenerima program CSR secara keseluruhan. Padahal kondisi kesejahteraan objektif antara keluarga penerima dan nonpenerima CSR berbanding terbalik. Fenomena ini dapat dijelaskan dengan pernyataan Syarief dan Hartoyo (1993) bahwa suatu keluarga walau tinggal di bawah garis kemiskinan, mungkin merasa lebih sejahtera, karena merasa lebih bersyukur atas karunia-Nya, merasa semua keinginannya sudah terpenuhi, merasa telah hidup selaras dengan alam, dan alasan lainnya. Keluarga nonpenerima program CSR diasumsikan seperti pernyataan tersebut sehingga mereka walaupun lebih miskin namun cenderung lebih menerima apa yang ada.

Hasil uji regresi linear berganda menunjukkan bahwa faktor yang berpengaruh terhadap kesejahteraan objektif keluarga penerima program CSR adalah besar keluarga dan manfaat yang dirasakan. Besar keluarga memiliki pengaruh negatif terhadap kesejahteraan objektif keluarga. Hal ini sejalan dengan penelitian Muflikhati et al. (2010) dan Elmanora, Muflikhati, dan Alfiasari (2012) yang menyatakan bahwa keluarga dengan jumlah anggota keluarga lebih sedikit memiliki peluang lebih besar untuk sejahtera dibandingkan keluarga dengan jumlah anggota keluarga yang lebih banyak. Hal ini menunjukkan bahwa banyaknya jumlah anggota keluarga bukan merupakan potensi untuk meningkatkan kesejahteraan, tetapi justru menjadi beban karena dengan pendapatan keluarga yang sama, semakin banyak anggota keluarga akan menjadikan pendapatan per kapita menjadi semakin rendah. Manfaat yang dirasakan dari program CSR berpengaruh positif terhadap kesejahteraan keluarga penerima program
CSR. Hal ini menunjukkan bahwa apabila suatu program pemberdayaan keluarga dilaksanakan dengan sistem perencanaan yang baik akan berpengaruh terhadap peningkatan kesejahteraan keluarga. Setelah lima tahun pelaksanaan program CSR Tambang Batulicin, saat ini telah dapat terlihat hasil yang cukup positif.

Hasil uji statistik dengan menggunakan regresi linear berganda menunjukkan bahwa faktor yang berpengaruh terhadap kesejahteraan subjektif keluarga penerima program CSR adalah status pekerjaan istri dan manfaat yang dirasakan dari program CSR. Status pekerjaan istri dan manfaat yang dirasakan dari program CSR memiliki pengaruh positif terhadap kesejahteraan keluarga penerima program CSR. Apabila seorang istri dalam suatu keluarga memiliki pekerjaan tetap, yang tentunya memiliki penghasilan yang tetap pula maka keluarga tersebut merasa lebih sejahtera. Hal ini sejalan dengan studi Widyanti et al. (2009) yang menyatakan bahwa bertambahnya orang dewasa yang bekerja dalam rumah tangga akan sangat berpengaruh positif terhadap kapasitas dan kondisi ekonomi keluarga. Pengukuran terhadap kesejahteraan subjektif dalam penelitian ini tidak terlepas dengan kepuasan terhadap kondisi keuangan keluarga. Kondisi ekonomi keluarga yang baik dapat menciptakan kepuasan bagi suatu keluarga. Terwujudnya kondisi ekonomi keluarga yang lebih baik, salah satunya dapat melalui istri yang bekerja dan memiliki penghasilan untuk keluarganya.

Manfaat yang dirasakan dari program CSR berpengaruh positif terhadap kepuasan yang dirasakan oleh penerima program tersebut. Kepuasan tersebut dapat tercapai karena terbukanya kesempatan bagi keluarga-keluarga miskin di lokasi penelitian untuk meningkatkan kesejahteraannya melalui perilaku keterlibatan dalam program CSR. Walaupun hasil penelitian menunjukkan bahwa peningkatan kesejahteraan secara objektif belum meningkat secara signifikan, namun kepuasan secara subjektif dapat terwujud karena keluarga-keluarga tersebut merasa telah berusaha dan melakukan proses agar kesejahteraan keluarga mereka dapat meningkat.

Hasil lainnya juga menunjukkan bahwa faktor yang berpengaruh terhadap kesejahteraan objektif keluarga di sekitar tambang adalah keikutsertaan dalam program CSR dan besar keluarga. Keikutsertaan dalam program CSR memiliki pengaruh positif terhadap kesejahteraan objektif keluarga. Keluarga yang mengikuti 
program CSR memiliki kesempatan untuk meningkatkan kesejahteraan objektif keluarganya yang terlihat pada peningkatan pendapatan per kapita. Program CSR, baik di bidang ekonomi, pendidikan, dan kesehatan memberikan manfaat secara langsung terhadap keluarga yang mengikutinya. Keluarga yang mengikuti program CSR di bidang ekonomi memperoleh pinjaman modal yang dapat digunakan untuk kegiatan usaha. Keuntungan yang diperoleh dari kegiatan usaha tersebut merupakan tambahan pendapatan bagi keluarga. Keluarga yang mengikuti program CSR di bidang pendidikan memperoleh beasiswa berupa SPP sekolah gratis karena telah ditanggung oleh CSR Tambang Batulicin, sehingga uang yang dialokasikan untuk membayar SPP sekolah dapat ditabung. Keluarga yang mengikuti program CSR di bidang kesehatan memiliki penambahan ketrampilan dari kegiatan pelatihan-pelatihan kesehatan. Ketrampilan yang bertambah dapat digunakan sebagai softskill untuk meningkatkan pendapatan keluarga.

Sama halnya dengan kesejahteraan objektif keluarga penerima manfaat CSR, besar keluarga juga memiliki pengaruh negatif terhadap kesejahteraan objektif keluarga di sekitar tambang. Namun yang menarik, besar keluarga juga memiliki pengaruh secara signifikan dan positif terhadap kesejahteraan subjektif keluarga di sekitar tambang. Hal ini terkait dengan upaya bertahan hidup yang dirasakan oleh keluarga. Keluarga dengan jumlah anggota keluarga yang lebih banyak merasa memiliki banyak sumberdaya untuk membantu melakukan upaya agar keluarganya tetap dapat bertahan hidup, membantu meningkatkan kesejahteraan dan memperoleh banyak dukungan moril sehingga secara subjektif mereka merasakan kepuasan yang lebih tinggi dibandingkan dengan keluarga yang memiliki jumlah anggota keluarga sedikit.

\section{SIMPULAN DAN SARAN}

Kesejahteraan keluarga meningkat setelah menerima program CSR. Keluarga memandang bahwa pelaksanaan program CSR Tambang Batulicin berjalan dengan baik, terutama dalam hal kepedulian terhadap masyarakat, kebermanfaatan program, tujuan program, kontribusi program dalam hal fasilitas desa, kontribusi dalam hal kesehatan masyarakat, kualitas pelaksanaan program, pengaruh bantuan terhadap perekonomian keluarga, serta pengaruh CSR terhadap kesejahteraan keluarga. Keluarga juga mendapatkan manfaat yang cukup dari program CSR.
Besar keluarga memengaruhi kesejahteraan keluarga baik secara objektif maupun subjektif. Kesejahteraan objektif keluarga juga dipengaruhi oleh keikutsertaan dalam program CSR. Sementara itu, kesejahteraan keluarga penerima program CSR baik secara objektif maupun subjektif dipengaruhi oleh manfaat yang dirasakan dengan adanya program CSR. Kesejahteraan objektif keluarga penerima program CSR juga dipengaruhi oleh besar keluarga, sedangkan kesejahteraan subjektif keluarga penerima program CSR juga dipengaruhi oleh status pekerjaan istri.

Berdasarkan simpulan, penelitian ini menyarankan perlu adanya penentuan sasaran penerima program CSR harus lebih valid dan tidak semata-mata menggunakan data kemiskinan sebelumnya karena dapat saja terjadi rumah tangga yang sebelumnya dikategorikan tidak miskin, ternyata saat pendataan masuk kategori keluarga miskin, atau sebaliknya. Selain itu, perlu juga dilakukan sosialisasi mengenai berbagai program CSR secara intens dengan periode waktu tertentu dan merata. Setelah memberikan CSR, diperlukan juga bimbingan atau pendampingan usaha yang lebih intensif bagi para keluarga yang meminjam dana mitra sebagai modal usaha untuk mengurangi terjadinya kegagalan usaha dan terbelitnya suatu keluarga dalam hutang yang lebih besar.

\section{DAFTAR PUSTAKA}

Elmanora, Muflikhati, I., \& Alfiasari. (2012). Kesejahteraan keluarga petani kayu manis. Jur. IIm. Kel. \& Kons., 5(1), 58-66.

Karlos. (2009). Dampak program kemitraan dan bina lingkungan PT Perkebunan Nusantara III Kebun Rantauprapat terhadap pendapatan dan kesejahteraan masyarakat di Kabupaten Labuhanbatu. Jurnal Perencanaan dan Pengembangan Wilayah, 4(3), 153-162.

Mapisangka, A. (2009). Implementasi CSR terhadap kesejahteraan hidup masyarakat, JESP, 1(1), 39-47.

Muflikhati, I., Hartoyo, Sumarwan, U., Fahrudin, A., \& Puspitawati, H. (2010). Kondisi sosial ekonomi dan tingkat kesejahteraan keluarga: kasus di wilayah pesisir Jawa Barat. Jur. IIm. Kel. \& Kons., 3(1), 1-10. 
Simanjuntak, M., Puspitawati, H., \& Djamaludin, M. D. (2010). Karakteristik demografi, sosial, dan ekonomi keluarga penerima Penerima Program Keluarga Harapan (PKH). Jur. Ilm. Kel. \& Kons., 3(2), 101113.

Syarief, H., \& Hartoyo. (1993). Beberapa aspek dalam kesejahteraan keluarga. Seminar Keluarga Menyongsong Abad 21 dan Peranannya dalam Pengembangan Sumberdaya Manusia Indonesia. Bogor: GMSK, Fakultas Pertanian. Institut Pertanian Bogor dan BKKBN, Bogor.
Wibisono, Y. (2007). Membedah konsep dan aplikasi CSR (Corporate Social Responsibility). Gresik, ID: Fascho Publishing.

Widyanti, W., Suryahadi, A., Sumarto, S., \& Yumna, A. (2009). The relationship between chronic poverty and household dynamics: Evidence from Indonesia/Jakarta, SMERU Research Institute, 2009. SMERU Working Paper, Jakarta. 